\title{
アンカーボルト初期張力や柱軸力の効果を 考慮した平面露出柱脚簡易解析モデル \\ SIMPLE ANALYSIS MODEL FOR EXPOSED COLUMN-BASE \\ CONSIDERING EFFECT OF INITIAL TENSIONING OF ANCHOR BOLTS AND COLUMN AXIAL FORCE
}

\author{
玉井宏章*1, 山西央朗*2, 白木 剛*3, 高松隆夫*4, 松尾彰*5
Hiroyuki TAMAI, Teruaki YAMANISHI, Tsuyoshi SHIRAKI, Takao TAKAMATSU and Akira MATSUO

\begin{abstract}
This paper presents a two-dimensional structural model of an exposed column-base, that take into account initial tensioning of anchor bolts and column axial force. The applicability of this model is confirmed through loading tests on a canti-lever with exposed column-base subjected to horizontal forces.

The following observations were made:

1) The model take into account of variation of rotational rigidity due to initial anchor bolts tensioning and axial force of column-base.

2) The model adjust the maximum bending moment capacity and rotational rigidity by changing the line of action of the compressive force line and rigidity modification coefficient.

3) The result from the present model agree closely with loading-tests results.
\end{abstract}

Keywords : Analysis model, Exposed column-base, Semi-rigidity 解析モデル，露出柱脚，半剛接特性

1. はじめに

柱脚は，上部建築物と下部基礎とをつなぐ重要な構造要素であ る。柱脚の中でも，鉄骨露出柱脚は，半剛接接合状態となってお り，アンカーボルトが先行して降伏する場合では，柱軸力により 曲げ耐力や弾性回転剛性（固定度）が変化する1) 3)ことは周知のこ とである。

この柱脚の固定度に着目し, 柱脚の解析モデルを作成して, 骨 組の地震応答を調査した研究は, 加藤ら ${ }^{4)}$, 河野・松井ら ${ }^{5)}$, 山田 秋山ら 6)によって行われている。 山田・秋山らは, 露出柱脚特有 の履歴である，いわゆるダブルフラッグ型の復元力特性を表すモ デルを用いる重要性を指摘し，これを用いて平面架構の地震応答 解析を行って，その耐震性能の検討を行っている。

著者等も, 文献 7 で平面架構の露出柱脚について, 2 種類の半 剛接状態を表すことができ, 軸力変動が曲げ耐力, 回転剛性に及 ぼす影響を考慮した解析手法を提案し，その精度を実験とつき合 わせて検討している7).
しかしながら, 文献 7 の方法は, 合応力空間で半剛接状態を判 別するため，どの状態にあるかを力学的に判断しやすく半剛接状 態を厳密に導入できるという利点がある反面，アンカーボルト初 期張力の効果を考慮したり，立体解析モデルに拡張する際に，場 合分けが多くなり，解析プログラムの定式化が複雑となる。ま た，一般に，露出柱脚の抵抗特性は，ベースプレートと基礎との 接触問題, ベースプレートの曲げ変形問題が内存している。 そこ で，本研究では，アンカーボルトを引張バネに，基礎コンクリー 卜を圧縮バネに置換し，接触・離間判定を離散化し，基礎に剛性 調整用の回転バネを有する簡易な平面露出柱脚解析モデルを考え る。このモデルは, 柱軸力やアンカーボルト初期張力の影響を考 慮でき, 解析プログラムも簡単化できる。また, 将来，2 軸曲げ を取り扱うための立体解析モデルに容易に拡張できると考元られ る。

次節以降では，まず，この平面柱脚解析モデルを導出し，アン カーボルト初期張力を変えて軸力と曲げを受ける露出柱脚付実大
*1 広島工業大学工学部建築工学科 准教授 - 博士 (工学)

*2 広島工業大学大学院工学研究科知的機能科学専攻 大学院生・修士 (工学)

*3 広島工業大学大学院工学研究科建設工学専攻 大学院生

*4 広島工業大学工学部建築工学科 教授・Ph.D.

*5 広島大学大学院工学研究科社会環境システム専攻 教授. 工博
Assoc. Prof., Faculty of Eng., Hiroshima Institute of Technology, Dr. Eng. Graduate Student, Graduate School of Eng., Hiroshima Institute of Technology, M. Eng.

Graduate Student, Graduate School of Eng., Hiroshima Institute of Technology Prof., Faculty of Eng., Hiroshima Institute of Technology, Ph. D.

Prof., Graduate School of Eng., Hiroshima University, Dr. Eng. 

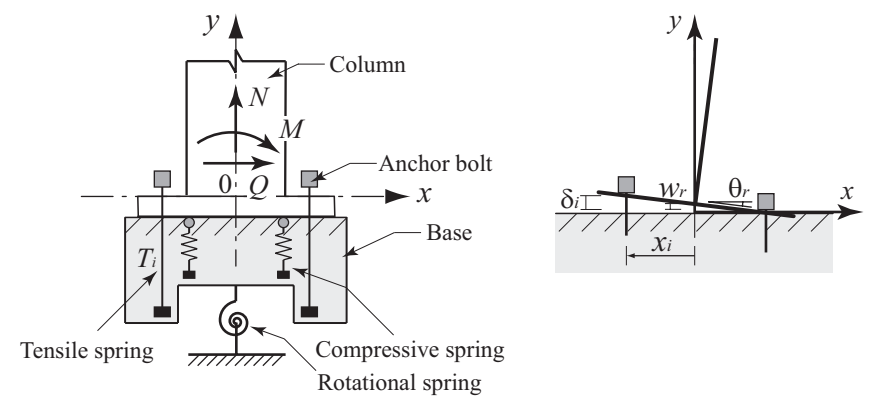

Fig. 1 Structural model for exposed column-base

Fig. 2 Nomenclature of generalized displacement parameter

片持柱について解析を行い, 既報の実験值と比較して, 本解析モ デルの有用性, 妥当性を検証する。

\section{2. 解析モデルの概要}

$\bigcirc$ 仮定と特徵

柱脚の構造モデルをFig. 1 に示す。本研究では, アンカー ボルトが先行して降伏する露出柱脚を対象とする。

本構造モデルは，アンカーボルト位置に引張弾塑性バネ を, 柱図心に対して対称に圧縮弾塑性バネと基礎の弾性回転 変形を表す回転バネを設置したものである。解析モデルの仮 定を以下のように設定する。

1) ベースプレートの塑性変形及び基礎部に破壊は生じない.

2) アンカーボルトは, せん断降伏せず，かつ，柱脚部のせ ん断方向の相対変形は無視できる。

3）基礎からの圧縮反力は, ある回転中心線に集中して生じ, 同一の抵抗機構では, その位置は変動しない.

4) ベースプレートと基礎との間の離間変位は, 回転中心線 を起点に直線的に変化する。

5 ) ベースプレート及び基礎の弾性変形による回転剛性の低 下の度合いは, 弾性時のアンカーボルトの伸び量から求 める回転剛性と比例関係にある。

6) アンカーボルトと基礎コンクリートとの付着の影響は無 視でき，アンカーボルト端部の定着は完全である。

また, 本解析モデルの特徵は, 以下のように列挙できる.

1)上部構造との連成効果, 特に, 軸力, アンカーボルト初 期張力の固定度や耐力に及ぼす影響を考慮できる。

2) 柱脚の圧縮反力位置の移動が表現でき, 引張軸力が作用 した時の耐力劣化特性を表せる。

3) 柱脚特有のダブル・フラッグ型履歴特性と回転スリップ 現象を追跡しうる。

4) 基礎コンクリートやベースプレートの変形に伴う，弾性 回転剛性の低下を，実状に合うように調整できる。

変位場

Fig.2 のような，2 次元座標を置き，2並進自由度と 1 回転 自由度の計 3 自由度のパラメー夕を用いて, ベースプレート 面上の各バネ位置における $y$ 軸方向変位: $\delta_{i}$ を次式で表す.

$$
\delta_{i}=w_{r}-x_{i} \cdot \theta_{r}
$$

ここに, $w_{r}, \theta_{r}$ は, $y$ 方軸方向変位, 回転の一般化変位パラ

メー夕（回転は，右回りを正方向とする。）， $x_{i}$ は， $i$ 番目の バネの $x$ 座標値である.

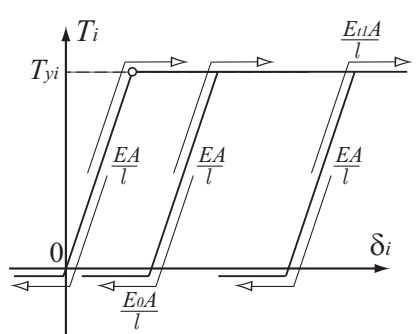

(a) Hysteresis of tensile spring (Anchor bolts)

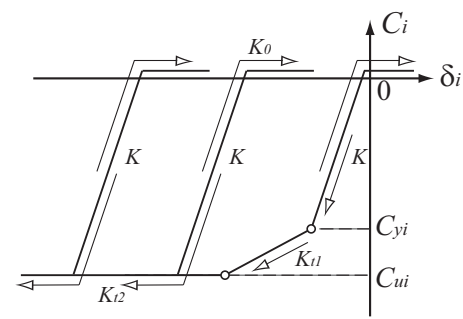

(b) Hysteresis of compressive spring (Base concrete)
Fig. 3 Hysteresis rule of tensile and compressive spring

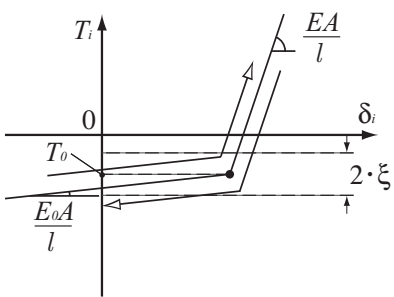

(a) Tensile spring

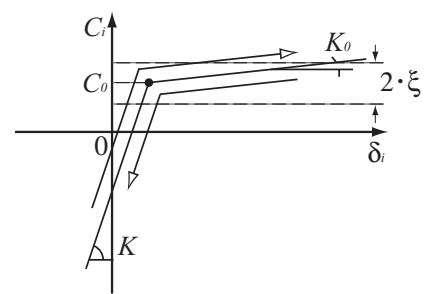

(b) Compressive spring
Fig. 4 Treatment for contact and separation condition of tensile and compressive spring

引引張・圧縮バネの履歴特性と接触・離間の取り扱い アンカーボルトおょび基礎コンクリートとベースプレート との間の抵抗特性を考慮し, Fig. 3(a), (b) に示す, 引張力: $T_{i}$ に抵抗するバネと圧縮力： $C_{i}$ に抵抗する弾塑性バネにより, それらの特性を表す。各バネの抵抗しうる荷重領域では, 材 の塑性化に伴う剛性低下をPoly - linear 型直線で表し, 離間 に伴う抵抗力の消失や，再接触に伴う回復は，Fig．4(a)，(b) に示すような, 非零の微小剛性を有する弾性バネとして取り 扱って, 材の離間・再接触時の特性を表す。接触・離間は, 次式で判定する.

$\left|T_{i}-T_{0_{i}}\right|<\xi$ を満足し,

離間かつ $\Delta \delta_{i}>0$ の時,

状態を接触に変更する。

接触かつ $\Delta \delta_{i}<0$ の時,

状態を離間に変更する。

ここに, $T_{i}$ : アンカーボルト軸力, $T_{0 i}$ : 離間軸力, $\xi$ : 微小 幅, $\Delta \delta_{i}: y$ 方向変位増分である。

$\left|C_{i}-C_{0 i}\right|<\xi$ を満足し,

離間かつ $\Delta \delta_{i}<0$ の時,

状態を接触に変更する。

接触かつ $\Delta \delta_{i}>0$ の時,

状態を離間に変更する。

ここに, $C_{i}$ : 基礎反力, $C_{0 i}$ : 離間反力である.

○初期の柱軸カとアンカーボルト導入張力の考慮

初期の柱軸力やアンカーボルト導入張力によっても柱脚の 耐力や回転剛性は変化する。これは, 圧縮・引張バネに初期 力を付与することで表現できる.

先ず，初期の柱軸力: $N_{0}$ に釣り合う圧縮反力: $C_{i}$ を導入した 後, アンカーボルト初期張力: $T_{0 i}$ に釣り合う圧縮反力増分 : $\Delta C_{i}$ を付加する。各導入過程の釣り合い式は次式となる。 


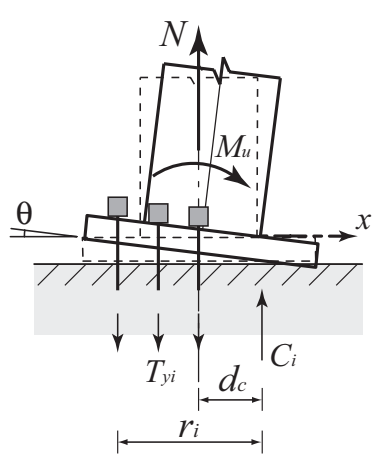

Fig. 5 Resisting mechanism of column-base

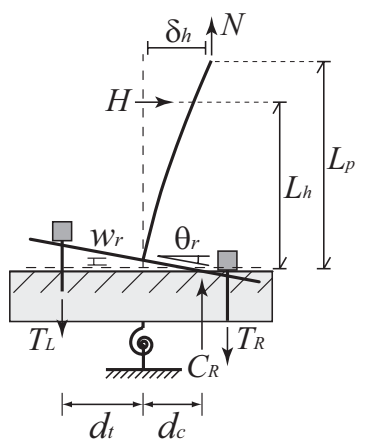

Fig. 6 Illustration of measured value in tests and analysis
初期の柱軸力 : $N_{0}$ の導入過程

$$
N_{0}+\sum_{i}^{n_{c}} C_{i}=0
$$

アンカーボルト初期張力: $T_{\theta i}$ の導入過程

$$
\sum_{i}^{n} T_{0 i}-\sum_{i}^{n} \Delta C_{i}=0
$$

ここに, $\Delta C_{i}$ : 圧縮反力増分, $C_{i}$ : 圧縮反力, $n_{c}$ : 圧縮バネ の個数, $n_{t}$ : 引張バネの個数である.

上述のような系として釣り合った状態を初期状態として解析を行う. $\bigcirc$ 圧縮合力線距離の設定

柱脚の最大抵抗曲げモーメント： $M_{u}$ は, 引張側アンカーボ ルトが全塑性軸力： $T_{Y i}$ に達したときに生じる。従って, Fig. 5 からわかるように, アンカーボルトの位置: $r_{i}$ の值と圧縮合力 線距離: $d_{c}$ が決まれば, 最大抵抗曲げモーメント值は定まる.

本解析モデルは, 最大抵抗モーメントが設定值となるよ う，モデルの圧縮合力線距離: $d_{c}$ を以下の手順で定める.

Fig. 5 での最大抵抗曲げモーメント : $M_{u}$ は, 圧縮合力が作用 する直線と柱図心との距離を $d_{c}$ とすると, 次式で表される.

$$
M_{u}=-N \cdot d_{c}+\sum^{T} T_{Y_{i}} \cdot r_{i}
$$

ここに, $T_{Y i}, r_{i}$ は, $i$ 番目のアンカーボルトの全塑性軸力及 びアンカーボルトと圧縮合力線との距離である. $\sum^{T}$ は, 引張 側アンカーボルト注1)についての総和を表す。また， $r_{i}$ は次式 で表される。

$$
r_{i}=d_{c}-x_{i}
$$

従って, $(5 . \mathrm{a}, \mathrm{b})$ 式を整理すると, 圧縮合力線距離: $d_{c}$ は, 次 式で得られる。

$$
d_{c}=\frac{M_{u}+\sum^{T} T_{Y_{i}} \cdot x_{i}}{\sum^{T} T_{Y i}-N}
$$

また, 圧縮合力線距離は, 柱軸力が比較的大きいときは、 柱フランジ端と図心との間の距離にとればょく ${ }^{8)}$, 最大曲げ モーメントは, 実験值や文献 10 のようなベースプレートと 基礎との接触を考慮した有限要素法解析值を用いることがで きよう。

\section{弾性回転剛性の調整について}

（1）式のように変位場を仮定すると，ベースプレートや基 礎は弾性変形を生じるため, 柱脚の回転剛性は実験值と較べ てかたくなる ${ }^{1), 2)}$ 。そこで, ベースプレートと基礎の弾性変 形の影響を考慮して, ベースプレートの回転角： $\theta$ は, アン カーボルトの変形に基因する基礎とベースプレートとの間の 相対回転角： $\theta_{r}$ と基礎及びベースプレートの弾性変形に基因 する回転角： $\theta_{b}$ との和として，次式で表す.

$$
\theta=\theta_{r}+\theta_{b}
$$

柱脚下端部の曲げモーメント増分： $\Delta M$ と基礎及びベース プレートの弾性変形に基因する回転角増分： $\Delta \theta_{b}$ との間には, 次の関係があると仮定する。

$$
\begin{aligned}
& \Delta M=K_{b} \cdot \Delta \theta_{b} \quad \cdots \cdots \cdot \cdot \cdot \\
& \text { ここに } \\
& K_{b}=\frac{1}{R-1} \cdot \frac{d_{c}+d_{t}-\frac{N}{T_{Y}} \cdot d_{c}}{\left(1-\frac{T_{0}}{T_{Y}}\right) \cdot\left(d_{c}+d_{t}\right)} \cdot K_{r}
\end{aligned}
$$

であり，

$$
K_{r}=\frac{E_{L} \cdot A_{L}}{\ell_{L}} \cdot\left(d_{c}+d_{t}\right)^{2}
$$

$\left(E_{L}, A_{L}, \ell_{L}, T_{0}, T_{Y}\right)$ は, 引張側アンカーボルトのヤング率, 総 断面積及びナット間長さ, 総初期導入張力, 総降伏軸力であ $\eta,\left(d_{c}, R\right)$ は, 圧縮合力線と柱図心との間の距離, 弾性回転剛 性補正係数である。また, $d_{t}$ は, 引張側アンカーボルト群の平 均的な位置と柱図心との間の距離であり, 次式で定義される。

$$
d_{t}=2 \cdot \frac{\sum_{i}^{T} A_{i} \cdot r_{i}}{\sum A_{i}}-d_{c}
$$

ここに, $\sum^{T}$ は, 引張側アンカーボルトについての総和を表す注1). 尚, (11.a) 式, (11.c) 式の導入の詳細は, 付録 A, B に示す. 弾性回転剛性補正係数: $R$ は, 基礎の弾性変形やベースプ レートの曲げ変形を勘案して, 柱脚の弾性回転剛性を実状に 合うように調整する量であり, 今後, よく利用される断面に ついて実験值をもとに值を設定する必要がある.

\section{○圧縮バネ特性の設定}

圧縮バネのバネ特性は, 基礎コンクリートの圧縮反力を表 現し, 過度の沈下を生じないように, 以下の手順で決定する。

いま，曲げモーメントと軸力を受ける柱脚を考える。引張 側アンカーボルトを集約した軸剛性: $K_{t}$ の引張バネと基礎コン クリートの圧縮反力を表す軸剛性： $K_{c}$ の圧縮バネが柱図心か ら $d_{t}$ 及び $d_{c}$ にあり, 柱軸力 $: N$ と曲げモーメント $: M$ が柱脚に 作用し, ベースプレート回転角: $\theta_{r}$ と $y$ 軸方向変位: $w_{r}$ が生じて いる。この状態に打ける柱軸力増分： $\Delta N$ と曲げモーメント増 分: $\Delta M$ は, 次式で表される.

$$
\begin{aligned}
& \Delta M=K_{t} \cdot\left(\Delta w_{r}+d_{t} \cdot \Delta \theta_{r}\right) \cdot d_{t}-K_{c} \cdot\left(\Delta w_{r}-d_{t} \cdot \Delta \theta_{r}\right) \cdot d_{c} \\
& \Delta N=K_{t} \cdot\left(\Delta w_{r}+d_{t} \cdot \Delta \theta_{r}\right)-K_{c} \cdot\left(\Delta w_{r}-d_{t} \cdot \Delta \theta_{r}\right)
\end{aligned}
$$

$(12 . \mathrm{a}, \mathrm{b})$ 式から, 柱軸力が変化しない時 $(\Delta N=0)$ のベースプ レートと基礎の間の回転剛性は, 次式で表される. 


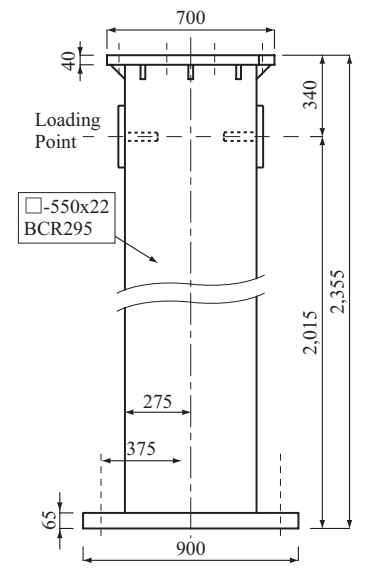

(a) Column

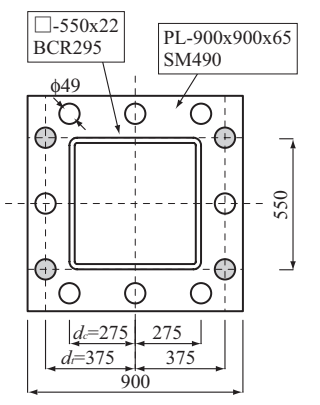

(b) Base plate

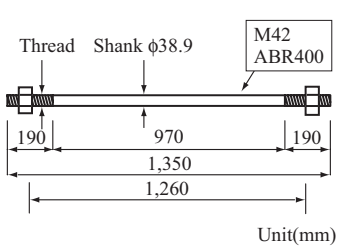

(c) Anchor bolt
Fig. 7 Test specimen

$$
\frac{\Delta M}{\Delta \theta_{r}}=\frac{K_{t} \cdot K_{c}}{K_{t}+K_{c}} \cdot\left(d_{c}+d_{t}\right)^{2}
$$

(11.b) 式と (13) 式との誤差を(11.b) 式の $\alpha$ 倍に抑えるよう $K_{c}$ を求めると， $K_{c}$ は次式で表される.

$$
K_{c}=\frac{1+\alpha}{\alpha} \cdot K_{t}=\frac{1+\alpha}{\alpha} \cdot \frac{E_{L} \cdot A_{L}}{\ell_{L}}
$$

$\alpha$ は，たとえば $0.1 \%(0.001)$ 程度の小さな值とすれば良く, 本論文の解析では $0.1 \%$ を採用している.

圧縮バネの第 1 ・第 2 降伏荷重, 第 2 ・第 3 分枝剛性は, 各バ ネの負担支圧面積と基礎コンクリートの最大支圧応力度等の 実験值を参考に決定することになるが，本論文では，基礎コ ンクリートは弾性挙動のみを対象とすることにする。基礎部 の弾塑性変形や破壊, アンカーボルトの付着や端部の定着等 の影響は, 今後の研究課題とする。

弾性割線剛性について

ベースプレートを単調に回転させた時の原点とアンカーボ ルトが降伏する時点とを結ぶ弾性回転剛性は, 圧縮バネによ る回転剛性への影響が十分に小さいとして無視すると, 次式 のように表される。

$$
K_{B S}=\frac{M_{u}}{\theta_{b u}+\theta_{r u}}
$$

ここに,

$$
\begin{aligned}
& M_{u}=T_{Y} \cdot\left(d_{c}+d_{t}\right)-N \cdot d_{c} \\
& \theta_{r u}=\left\langle T_{Y} \cdot\left(d_{c}+d_{t}\right)-T_{0} \cdot\left(d_{c}+d_{t}\right)\right\rangle / K_{r} \\
& \theta_{b u}=\left\langle T_{Y} \cdot\left(d_{c}+d_{t}\right)-N \cdot d_{c}\right\rangle / K_{b}
\end{aligned}
$$

(16.a c) 式及び (11.a), (11.b) 式を(15.a) 式に代入し，整理す ると, 弾性割線剛性: $K_{B S}$ は次式で与えられる。

$$
K_{B S}=\frac{E_{L} \cdot A_{L}}{R \cdot \ell_{L}}\left(d_{c}+d_{t}\right) \cdot \frac{d_{c}+d_{t}-\frac{N}{T_{Y}} \cdot d_{c}}{1-\frac{T_{0}}{T_{Y}}}
$$

\section{3. 試験体と解析シリーズ}

本解析モデルの有効性を検討するため, 軸力と曲げを受け

\begin{tabular}{|c|c|c|c|c|}
\hline \multirow{2}{*}{ Series } & $N_{0}$ & $T_{0}$ & $M_{u}$ & \\
\hline & $\mathrm{kN}$ & $\mathrm{kN}$ & $\mathrm{kN} \cdot \mathrm{m}$ & \\
\hline \multirow{3}{*}{ Test I } & -150 & 100 & 544 & \\
\hline & -150 & 300 & 544 & \\
\hline & -150 & 500 & 544 & \\
\hline \multirow{3}{*}{ Test II } & 0 & 200 & 502 & \\
\hline & -600 & 200 & 668 & \\
\hline & $-1,200$ & 200 & 833 & \\
\hline Test III & -400 & 150 & 612 & \\
\hline $\begin{array}{l}d_{c} \\
\mathrm{~mm}\end{array}$ & $\begin{array}{l}d_{t} \\
\mathrm{~mm}\end{array}$ & $\begin{array}{c}d \\
\mathrm{~mm}\end{array}$ & $\begin{array}{c}M_{Y} \\
\mathrm{kN} \cdot \mathrm{m}\end{array}$ & $\begin{array}{r}\theta_{Y} \\
\mathrm{rad}\end{array}$ \\
\hline 275 & 375 & 275 & 503 & $3.07 \times 10^{-3}$ \\
\hline
\end{tabular}

Table 1 Material and Sectional properties of members in Analysis (a) Column ( $\square-550 \times 22$, BCR295)

\begin{tabular}{lcccc}
\hline $\begin{array}{c}A_{c} \\
\mathrm{~mm}^{2}\end{array}$ & $\begin{array}{c}I_{\mathrm{c}} \\
\mathrm{mm}^{4}\end{array}$ & $\begin{array}{c}Z_{p} \\
\mathrm{~mm}^{3}\end{array}$ & $\begin{array}{c}L_{h} \\
\mathrm{~mm}\end{array}$ & $\begin{array}{c}\sigma_{y} \\
\mathrm{~N} / \mathrm{mm}^{2}\end{array}$ \\
\hline \hline $4.48 \times 10^{4}$ & $2.04 \times 10^{9}$ & $8.75 \times 10^{6}$ & 2,015 & 295 \\
\hline$A_{c}:$ Sectional area, $I_{c}:$ Moment of inertia, \\
$Z_{p}:$ Plastic section modulus, \\
$L_{h}:$ Length of column as shown in Fig. 6, \\
$\sigma_{y}:$ Yield stress
\end{tabular}

(b) Anchor bolt (M42, ABR400)

\begin{tabular}{cccc}
\hline $\begin{array}{c}A_{L} \\
\mathrm{~mm}^{2}\end{array}$ & $\begin{array}{c}\ell_{L} \\
\mathrm{~mm}\end{array}$ & $\begin{array}{c}\sigma_{y} \\
\mathrm{~N} / \mathrm{mm}^{2}\end{array}$ & $\begin{array}{c}\phi \\
\mathrm{mm}\end{array}$ \\
\hline \hline 2,380 & 1,260 & 325 & 38.9 \\
\hline$A_{L}:$ Sectional area of anchor bolts, \\
$\ell_{L}:$ Length between nuts, \\
$\sigma_{y}:$ Yield stress, $\phi:$ Diameter
\end{tabular}

Table 2 Analysis model parameters

$\theta_{Y}=M_{Y} / K_{r}$

$M_{Y}$ : Yield bending moment without axial force

$K_{r}$ : Elastic rotational rigidity due to elongation of tensile anchor bolts

$T_{Y}$ : Yield axial force in tensile anchor bolts

$R$ : Rotational rigidity modification coefficient

$d_{c}, d_{t}$ : Distance between centroid of column and reaction line, centroid of column and anchor bolt

$d$ : Column half width

る露出柱脚付片持柱の載荷試験に基づいて解析を行う。本節 では, その試験体と解析シリーズを示す。

用いた試験体をFig. 7 に示す。

試験体は， $\square-550 \times 22(\mathrm{BCR} 295)$ の角形鋼管柱に 12 個の孔を 有する PL-900x900x65(SM490)の既製品ベースプレートを溶 接し，図中べースプレートの斜線の孔の位置で転造ネジアン カーボルト（M42, ABR400) 4 本を用いて，鋼製基礎ばりと緊結 した露出柱脚付片持柱である。尚, ナット間の距離は $1,260 \mathrm{~mm}$ である。これら試験体の断面性能, 素材特性を Table 1 に示す，表中のベースプレートと柱の降伏応力度は，公称值であ る. Table 2 には, 解析モデルの設定パラメー夕を示す. 尚, 試 験体の基礎は鋼製であり，アンカーボルトには周面付着はな く，端部定着は完全となっている.

解析シリーズとして, 降伏曲げモーメント： $M_{u}$ の 0.8 倍を荷 重振幅とする弾性載荷解析について, 柱軸力: $N$ を $T_{Y}$ の - 0.19 倍 $(-150 \mathrm{kN})$ とし, 引張側アンカーボルトの初期導入張力: $T_{0}$ を $T_{Y}$ の $0.13,0.39,0.65$ 倍 $(100,300,500 \mathrm{kN})$ と変化させるシ 


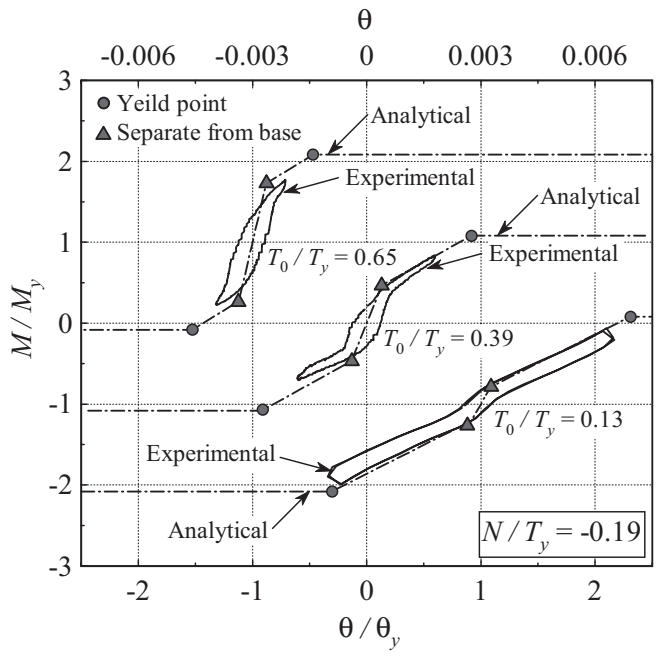

Fig.8 $M / M_{Y}$ vs. $\theta / \theta_{Y}$ relation in Series I

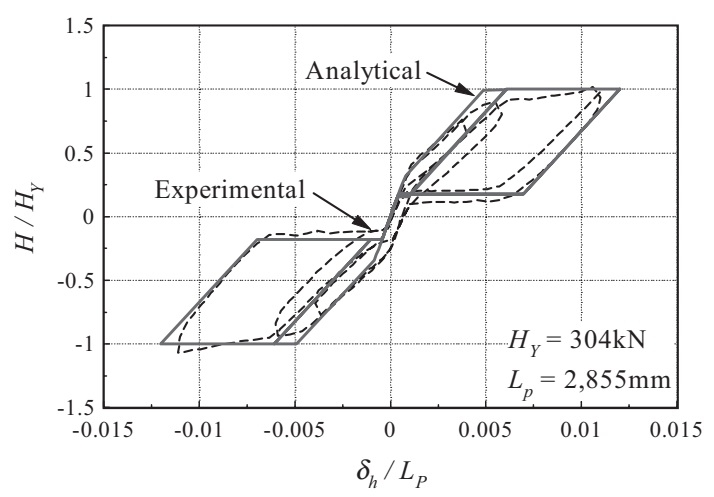

(a) $H / H_{Y}$ vs. $\delta_{h} / L_{p}$ relation

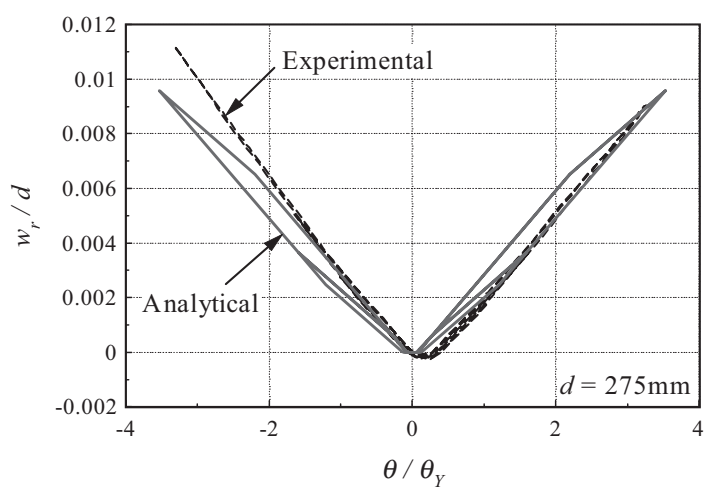

(c) $w_{r} / d$ vs. $\theta / \theta_{Y}$ relation

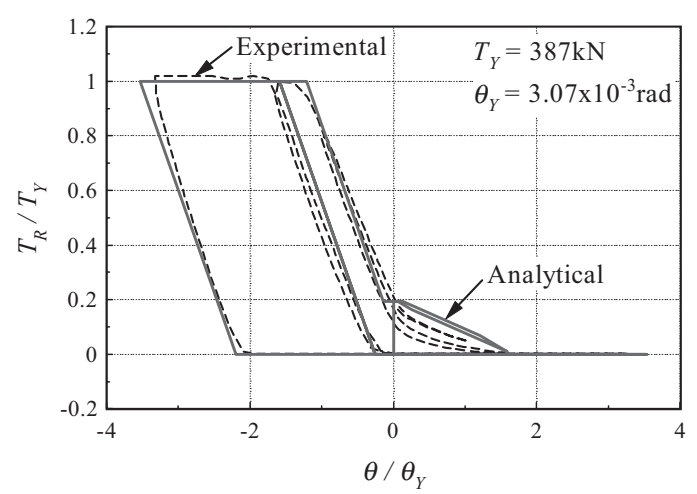

(e) $T_{R} / T_{Y}$ vs. $\theta / \theta_{Y}$ relation

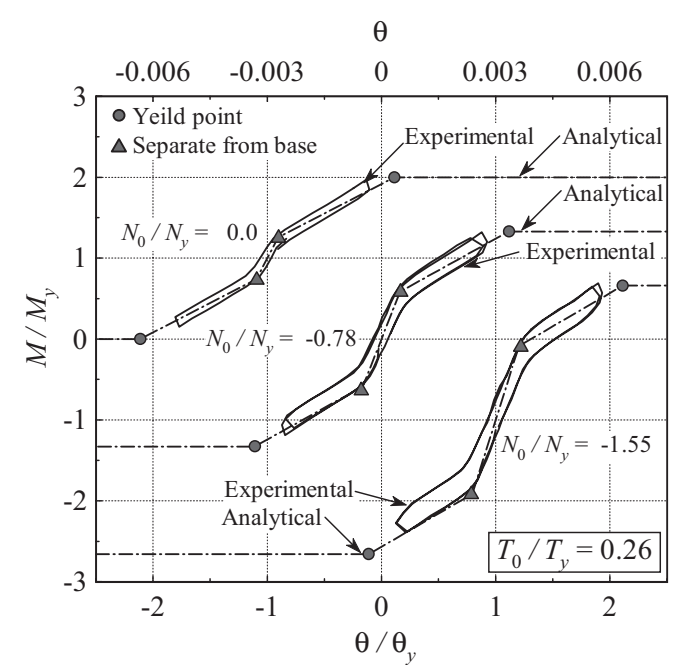

Fig.9 $M / M_{Y}$ vs. $\theta / \theta_{Y}$ relation in Series II

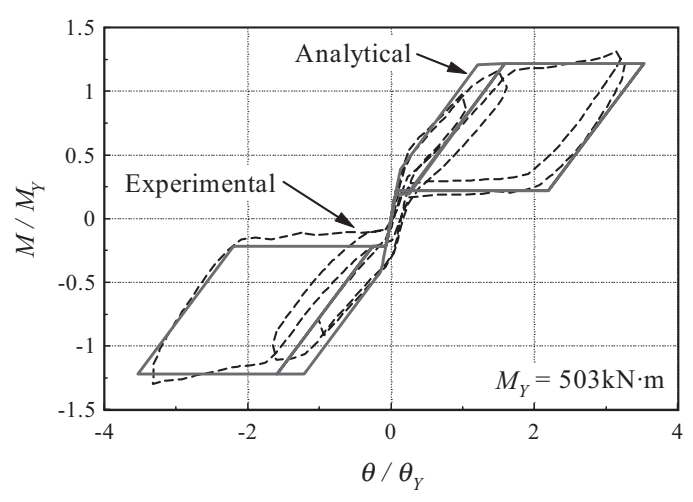

(b) $M / M_{Y}$ vs. $\theta / \theta_{Y}$ relation

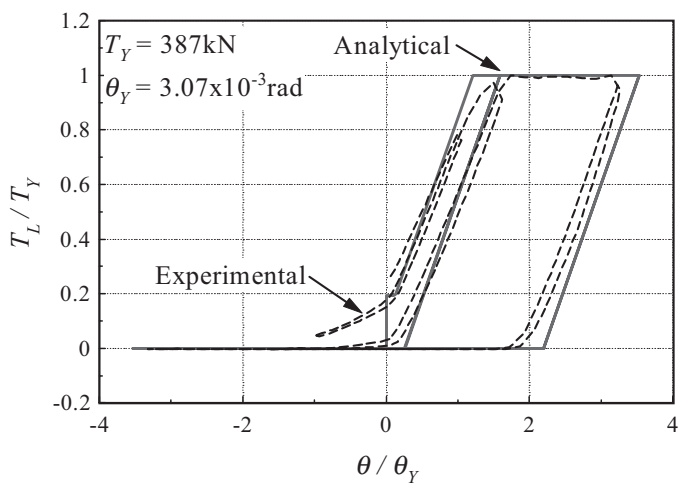

(d) $T_{L} / T_{Y}$ vs. $\theta / \theta_{Y}$ relation

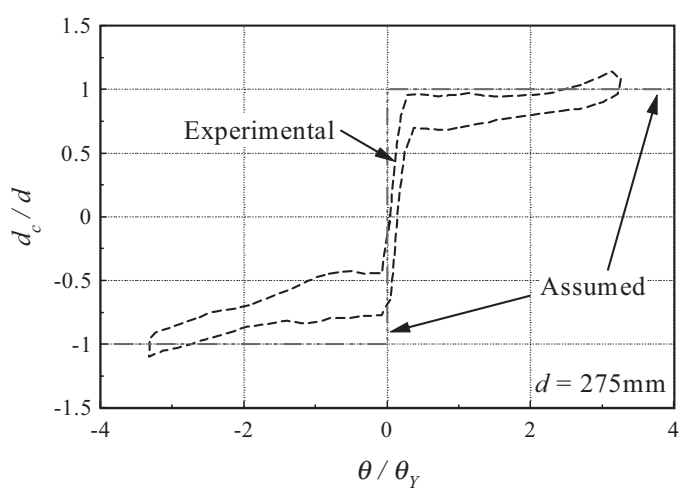

(f) $d_{c} / d$ vs. $\theta / \theta_{Y}$ relation

Fig. 10 Analytical results of Series III 
リーズ ( 解析シリーズ I ), 引張側アンカーボルトの初期導入 張力: $T_{0}$ を降伏軸力: $T_{Y}$ の 0.26 倍 $(200 \mathrm{kN})$ とし, 柱軸力: $N$ を, 引張側アンカーボルトの降伏軸力: $T_{Y}$ の $0.0,-0.78,-1.55$ 倍 $(0$, $-600,-1,200 \mathrm{kN})$ と変化させるシリーズ (解析シリーズ II ), 解 析シリーズ I・II と同様の試験体とし, 軸力: $N$ を $-400 \mathrm{kN}\left(N_{0} /\right.$ $\left.T_{Y}=-0.52\right)$, 引張側アンカーボルトの初期導入張力の和: $T_{0}$ を $150 \mathrm{kN}\left(T_{0} / T_{\gamma}=0.19\right)$ とし, 頂部変形角: $\delta_{h} / L_{p}$ の振幅を 0.00595 , $0.00119 \mathrm{rad}$ と漸増させ, 各振幅で 1 サイクル載荷する正負交 番漸増振幅繰り返し載荷解析（解析シリーズ III）の 3 つを用 意した。載荷装置の詳細については, 文献 9 を参照されたい. 尚, Table 2 中の $d_{c}$ は, 各シリーズの実験值から (6) 式で求めた 值の平均值を採用している。

\section{4. 解析結果とその考察}

解析シリーズ I の結果をFig. 8 に, 解析シリーズIの結果を Fig.9 に, 解析シリーズ IIIの結果をFig.10に，それぞれ，示す.

Fig. 8,Fig.9 には, 無軸力下の降伏曲げモーメントで無次元化し た柱脚の抵抗曲げモーメント: $\left(M / M_{Y}\right)$ と, 基礎とベースプレー トの弾性変形を無視した時の降伏回転角で無次元化したべー スプレート回転角: $\left(\theta / \theta_{Y}\right)$ の関係を, 実験值とともに示す.

尚, 計算值でのベースプレートと基礎とが離間する時点を ムで, アンカーボルトが降伏する時点を○で，それぞれ，示 している。また, 各解析・実験結果が重複して見づらいため, 対応する変数の解析結果・実験結果毎に横軸と縦軸を 1 グ リッド平行移動して示している。

Fig.10(a)には, 降伏水平力で無次元化した水平力: $\left(H / H_{Y}\right)$ と 頂部水平変形角: $\left(\delta_{h} / L_{p}\right)$ との関係を, Fig. $10(\mathrm{~b})$ には, 無軸力 下の降伏曲げモーメントで無次元化した柱脚の抵抗曲げモー メント： $\left(M / M_{Y}\right)$ と基礎とベースプレートの弾性変形を無視し た時の降伏回転角で無次元化したベースプレート回転角：( $\theta$ $\left(\theta_{Y}\right)$ との関係を,Fig. 10(c) には, 柱フランジと柱図心との間 の距離で無次元化した柱脚の鉛直方向相対変位: $\left(w_{r} / d\right)$ と $(\theta /$ $\left.\theta_{Y}\right)$ との関係を, Fig.10(d,e)には, 降伏軸力で無次元化した左 右アンカーボルトの軸力: $\left(T_{L} / T_{Y}, T_{R} / T_{Y}\right)$ と $\left(\theta / \theta_{Y}\right)$ との関係を, Fig. 10(f)には, 柱フランジと柱図心との間の距離で無次元化し た圧縮合力線距離: $\left(d_{c} / d\right)$ と $\left(\theta / \theta_{Y}\right)$ との関係を, それぞれ, 示す.

これらの結果から, 以下のことがわかる.

\section{○アンカーボルト初期導入張力の効果の評価}

Fig. 8 より，アンカーボルトの初期導入張力： $T_{0}$ を大きくす るにつれ, 第 1 ・第 2 分枝回転剛性は大きくなる。解析値は, $T_{0} / T_{Y}$ の值が $0.13 \sim 0.39$ の範囲内では, 実験值と良好に一致し, アンカーボルトの初期導入張力： $T$ 。が大きくなると, 弾性回 転剛性が大きくなるという傾向を表現しうることがわかる. $\bigcirc$ 柱の初期張力の効果の評価

Fig. 9 より，柱軸力: $N_{0}$ を大きくするにつれて，第 1 ・第 2 分 枝回転剛性は変化しないものの, 第 1 分岐曲げモーメント值 は大きくなることがわかる。解析值は, $N_{0} / T_{Y}$ の值が $0 \sim-1.55$ の範囲内では, 実験值と良好に一致し, 柱軸力: $N$ が大きくな ると第 1 分岐曲げモーメントが大きくなった結果, 弾性割線 剛性が大きくなるという傾向を表現しうることがわかる。 弾性回転剛性について
Fig. 10(a), (b) から, 載荷初期の第 1 - 第 2 分枝回転剛性と第 1 分岐曲げモーメント值は, 解析值が実験值と良好に一致し ていることがわかる。第 1 分岐曲げモーメント值と除荷時の 回転スリップ現象が生じる曲げモーメント值の差は, アン カーボルトの初期導入張力に基因している。従って, 本解析 モデルは, 柱軸力やアンカーボルト初期導入張力の弾性回転 剛性に及ぼす影響も良好に表せることがわかる。

\section{○履歴特性について}

Fig. 10(a), (b) から, 柱脚の最大耐力, 最大抵抗曲げモーメ ント及び除荷時の回転スリップが生じる耐力及び曲げモーメ ント值は, 解析值は実験值とほぼ等しい。 また, 解析值は, 実 験值の示すダブルフラッグ型の復元力特性を忠実に再現して いることがわかる。このことから, 最大抵抗曲げモーメント 值を適切に設定し, この值と (6) 式から圧縮合力線距離を評 価すれば, 本解析モデルは, 実験值とほぼ一致するダブルフ ラッグ型の復元力特性を再現できることがわかる.

\section{引張・圧縮バネの抵抗性状について}

Fig. 10(c)より, ベースプレートの回転により, ベースプレートと基 礎とが離間し，半剛接状態となり，柱脚の図心が浮き上がる現象が 生じる。回転バネのみ用いる通常のモデル化では，この現象を表せ ないが，本解析モデルはこの現象を再現していることがわかる.

Fig. 10(d), (e)より，各アンカーボルトの軸力とベースプレート回転角 との関係は, 解析值と実験值とが良好に一致していることがわかる.

Fig.1(a)に示すように, 回転剛性を補正する回転バネを配し, 回転剛性補正係数： $R$ を 1.5 と適正な值とすれば, 引張バネの抵 抗性状や柱脚の弾性回転剛性は実験值と整合することがわかる。

\section{圧縮合力線距離について}

本解析モデルは, 圧縮合力線距離は, 同一の抵抗性状機構 では, その位置は変化しないと仮定している。その妥当性を 考察する。Fig. 10(f) から, 圧縮合力線距離は, ほぼフラン ジ端及びベースプレート端位置にあり, 同一載荷方向では, 一定の值となっている。従って, 軸力が大きく変動しなけれ ば, 本解析モデルの仮定は妥当であることがわかる。

以上のことから, 本解析モデルは, 第 1 ・第 2 分枝回転剛 性, 第 1 分岐曲げモーメント, 降伏曲げモーメント及びス リップ時の曲げモーメントともに, 実験值をよく再現でき, 妥当なモデルであることがわかる.

\section{5. まとめ}

柱軸力やアンカーボルト初期張力の影響を考慮した簡易な 平面露出柱脚解析モデルを提案し, 4 本のアンカーボルトを 有する実大露出柱脚を対象とした実験結果と比較して, 解析 モデルの有用性, 妥当性を検討した。

得られた知見は以下のように要約できる。

1) アンカーボルト初期導入張力の増大に伴って, 第 1 ・第 2 分 枝回転剛性が増大する傾向や, 柱軸力の増大に伴って, 第 1 分岐曲げモーメント值が増大する傾向等の初期弾性挙動 を良好に再現しうる。

2)傘折れや圧縮折れと呼ばれるべースプレートの弾性曲げ 変形よって, アンカーボルト軸力挙動は本モデルと異な 
るが, ベースプレートがアンカーボルトの引張力で塑性 化しない範囲では, 回転剛性補正係数で調整することに より，アンカーボルトの抵抗特性は実験值と整合する。

3 ) 最大曲げ耐力は，圧縮合力線距離で，弾性回転剛性は，回転 剛性補正係数で調整すれば，繰返し載荷下における柱脚特 有の履歴性状，ダブルフラッグ型履歴特性と回転スリップ 現象を良好に追跡しうる。

本解析モデルは，2 節で示したように，柱軸力が圧縮から引張 に変化した時の耐力劣化特性も追跡できる。この実験結果と本解 析モデルによる検討については，報を改めて報告する予定である.

謝 辞

本研究は, 広島工業大学「高性能構造システム開発研究セ ンター」（代表者：高松隆夫教授）のプロジェクト研究の一 環として実施しました。また，本研究の経費の一部は，日本 学術振興会科学研究費補助金（代表者：玉井宏章 課題番号 18560569 ), 社団法人日本鉄鋼連盟「2005 年度鋼構造研究· 教育助成事業 (建築)」の助成金から支出しました。更に，フ ルサト工業株式会社より転造ねじアンカーボルトを提供して 頂いた。また，実験デー夕整理には，広島工業大学学生 三 好行則君, 平成 17 年度卒論生 藤井博規君には多大な協力 を得た。ここに記して，感謝の意を表します。

参考文献

1) 日本建築学会: 鋼管構造設計施工指針 - 同解説, pp.127-128, 1990 .

2) 日本建築学会: 鋼構造接合部設計指針, pp.255-279, 2006.3.

3) 玉井宏章：変動軸力と繰り返し曲げを受ける露出柱脚の載荷実験 変動軸力下の半剛接特性 -, 日本建築学会構造系論文集, 第 567 号, pp.149-156, 2003.5.

4) 加藤勉, 佐藤邦昭, 鎌形修一, 田上淳: 鋼構造露出型柱脚の復元力特 性が上部架構に与える影響について (その 1)( その2), 日本建築学会 大会学術講演梗概集, pp.867-870, 1986.8.

5) 河野昭雄, 松井千秋: 柱脚の復元力特性の違いがはり降伏型鉄骨ラー メンの地震応答性状に与える影響について, 日本建築学会構造系論 文集，第 507 号，pp.139-146，1998.5.

6) 山田哲，秋山宏，貞許美和：スリップ型の復元力特性を有する柱脚 の弾塑性挙動が鋼構造多層骨組の終局耐震性能に及ぼす影響, 日本 建築学会構造系論文集，第 502号, pp.141-147, 1997.12.

7) 玉井宏章：変動軸力の影響を考慮した露出柱脚付骨組の弾塑性解析 法，日本建築学会構造系論文集，第 571 号,pp.127-135,2003.9.

8) 秋山宏：鉄骨柱脚の耐震設計，技報堂，pp.20-29,pp.111-131, 1985 .

9) 玉井宏章, 高松隆夫, 山西央朗, 白木剛, 多田元英 : 統合化評価法 を用いた実大ノンスリップ型露出柱脚の仮動的実験, 鋼構造年次論 文報告集，第 14 巻, pp.269-276, 2006.11

10) 山西央朗，高松隆夫，玉井宏章，松尾彰：単調載荷下における鉄骨露 出誘客の FEM 解析, 鋼構造年次論文報告集, 第14巻, pp.689-696, 2006.11.

注

注 1 ) 引張側アンカーボルトとは, ベースプレート回転角が $0.03 \mathrm{rad}$ の時 においてアンカーボルト軸力が全塑性軸力: $T_{y}$ に達するアンカーボ ルトのことをいう.

付録 A 基礎回転バネ剛性の設定について

柱脚に軸力: $N$ と曲げモーメント：Mが作用し，アンカーボルトの伸び 量のみに基因するべースプレート回転角： $\theta_{r}$ が生じている.引張側アン カーボルトの降伏軸力は $T_{Y}$ で, 柱図心から $d_{t}$ の位置にあり, 初期導入張 力は $T_{0}$ であり, 基礎からの反力は, 柱図心から $d_{c}$ の位置にあるとする. その時の $M$ と $\theta_{r}$ との関係は, Fig. A-1 に示すようになる.

$M-\theta_{r}$ 関係で原点とアンカーボルトが降伏して最大抵抗曲げモーメント

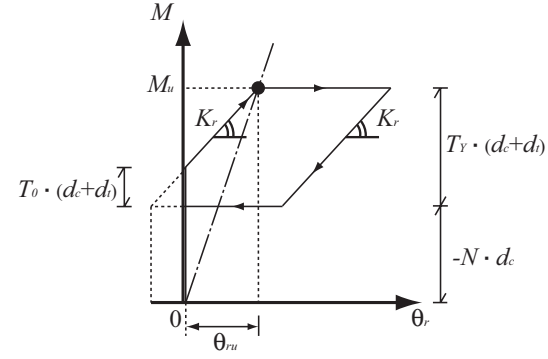

Fig. A-1 $M$ vs. $\theta_{y}$ relation

に達した点を結ぶ割線剛性： $M_{u} / \theta_{r u}$ は，次式で表される。

$$
\frac{M_{u}}{\theta_{r u}}=\frac{d_{c}+d_{t}-\frac{N}{T_{Y}} \cdot d_{c}}{\left(1-\frac{T_{0}}{T_{Y}}\right) \cdot\left(d_{c}+d_{t}\right)} \cdot K_{r}
$$

ここに

$$
K_{r}=\frac{E_{L} \cdot A_{L}}{\ell_{L}} \cdot\left(d_{c}+d_{t}\right)^{2}
$$

(11.a) 式は, (A-1) 式を参考に, $M_{u}-\theta_{r u}$ 関係における割線回転剛性: $K_{B S}$ が次式となるように回転剛性補正係数： $R$ を用いて仮定した。

$$
K_{B S}=\frac{E_{L} \cdot A_{L}}{R \cdot \ell_{L}} \cdot\left(d_{c}+d_{t}\right) \cdot \frac{d_{c}+d_{t}-\frac{N}{T_{Y}} \cdot d_{c}}{1-\frac{T_{0}}{T_{Y}}}
$$

(11.a) 式は, ベースプレート及び基礎の弾性変形に基因する回転剛性： $K_{b}$ は, 軸力: $N$ が圧縮で大きな值, アンカーボルト初期導入張力: $T_{0}$ が引 張で大きな值となると, ベースプレートと基礎との接触面が広がり, 剛 性值が大きくなる傾向を表したものである. $N=0, T_{0}=0$ 及び $R=2.0$ の時に は, (A-3) 式は，鋼管構造設計施工指針の式と一致する。

付録 B 引張側アンカーボルトの位置: $d$,について

本解析法は，1 本あるいは多数本のアンカーボルトを有する一般的な 露出柱脚を, 剛なべースプレートと左右対称に配置されたアンカーボル トにモデル化して，その抵抗性状を表す方法を採用する。露出柱脚の弾 塑性性状は, 主に $M-N$ 耐力相関関係と弾性回転剛性により特徵づけら れるので, $M-N$ 耐力相関関係及び半剛接状態での弾性回転剛性を近似 するようにモデルのパラメーラを決定する。簡単のため, 集約したアン カーボルトのヤング率, 断面積, 長さ, 初期降伏応力は, $\left(E, A, \ell, \sigma_{y}\right)$ と 表す.

解析モデル及び代表的柱脚部における，全アンカーボルトの降伏軸 力, 無軸力下におけるアンカーボルト降伏時の曲げモーメント及び弾性 回転剛性は，それぞれ，次式で求められる。

○解析モデル

$$
N_{Y}=2 \cdot A \cdot \sigma_{y}, \quad M_{Y}=A \cdot \sigma_{y} \cdot\left(d_{c}+d_{t}\right), \quad K_{\theta}=\frac{E \cdot A}{\ell} \cdot\left(d_{c}+d_{t}\right)^{2} \quad \cdots(\mathrm{B}-1 . \mathrm{a} \sim \mathrm{c})
$$

$\bigcirc$ 代表的柱脚

$$
N_{Y}=\sum_{i} A_{i} \cdot \sigma_{y i}, \quad M_{Y}=\sum_{i}^{T} A_{i} \cdot \sigma_{y i} \cdot r_{i}, \quad K_{\theta}=\sum_{i}^{T}\left(\frac{E_{i} \cdot A_{i}}{\ell_{i}} \cdot r_{i}^{2}\right) \quad \cdots(\mathrm{B}-2 . \mathrm{a} \sim \mathrm{c})
$$

ここに, $d_{c}$ : 柱図心から回転中心点（フランジ端）までの距離, $d_{t}$ : 柱 図心から解析モデルの引張側アンカーボルト軸心までの距離, $\left(E_{i}, A_{i}, \ell_{i}\right.$, $\left.\sigma_{y i}\right): i$ 番目のアンカーボルトのヤング率, 断面積, 長さ, 初期降伏応力, $r_{i}$ : 回転中心 (フランジ端) から $i$ 番目のアンカーボルト軸心までの距離, $\sum$ : 全アンカーボルトの総和, $\sum^{T}$ : 引張側アンカーボルトについての総和 である.

$E=E_{i}, \sigma_{y}=\sigma_{y i}$ とおくと, (B-1.a c c), (B-2.a c c) 式から, 解析モデルのパラ メー夕: $A, d_{t}, \ell$ は, 次式のように求まる.

$$
A=\frac{1}{2} \cdot \sum_{i} A_{i}, \quad d_{t}=2 \cdot \frac{\sum_{i}^{T}\left(A_{i} \cdot r_{i}\right)}{\sum_{i} A_{i}}-d_{c}, \quad \ell=\frac{\sum_{i} A_{i} \cdot\left(d_{c}+d_{t}\right)^{2}}{2 \cdot \sum_{i}^{T}\left(\frac{A_{i}}{\ell_{i}} \cdot r_{i}^{2}\right)} \quad \cdots(\mathrm{B}-3 . \mathrm{a} \sim \mathrm{c})
$$

